\title{
İmam Hatip Ortaokulu Öğrencilerinin Okul İklimi Algıları ile Okula Bağlılıkları Arasındaki İlişki ${ }^{1}$
}

\begin{abstract}
Ahmet $\mathrm{KOC}^{2}$
Öz

İmam Hatip Ortaokulu (İHO) öğrencilerinin okul iklimi algıları ile okula bağlllıkları arasındaki ilişkinin incelendiği bu araştırma, ilkokuldan sonra farklı bir akademik yapı içine giren ortaokul öğrencilerinin okullarına yönelik bakış açlarını tespit etmeye yöneliktir. Eğitim içeriğinin ve şeklinin bir neticesi olarak kendine has bir okul iklimi ve kültürünün oluştuğu İHO'da okuyan öğrencilerin okullarına yönelik görüssleri önem arz etmektedir. Okul iklimi ve okula bağlılık konusunda yönetici ve öğretmenlere yönelik pek çok araştırma yapılmış olsa da genelde öğrencilere yönelik özelde ise İHO öğrencilerine yönelik bu alanda yapılan çalışma oldukça azdır. Araştırma 2020 yılında, İstanbul'daki 11 İHO'da okuyan 481 öğrencinin katılımı ile gerçekleştirilmiştir. Nicel yöntemle yapılan araştırmada "Okul İklimi Ölçeği” ve “Okul Bağlılığı Ölçeği” kullanılmıştır. Araştırma sonuçlarına göre; kız öğrencilerin, daha alt sinıflarda okuyan öğrencilerin, ebeveyniyle beraber ikamet eden öğrencilerin, İHO’ya kendi tercihiyle gelen öğrencilerin ve İHO’dan sonra İmam Hatip Lisesinde ya da Fen Lisesinde okumak isteyen öğrencilerin okul iklimi algılarının ve okula bağlılıklarının diğer gruplara göre anlamlı düzeyde daha yüksek olduğu tespit edilmiştir. Öğrencilerin olumlu okul iklimi algıları ile okula bağlllıkları arasında pozitif ve anlamlı bir ilişki olduğu, okul iklimi alg1sı yüksek olan öğrencilerin okula bağl1liklarının da yüksek olduğu belirlenmiştir.
\end{abstract}

Anahtar Kelimeler: Din Eğitimi, İmam Hatip Ortaokulu, Okul İklimi, Okula Bağlllık, Okul Kültürü

\section{An Investigation of the Relationship between Imam Hatip Secondary School Students' School Climate Perceptions and School Engagements}

\section{Abstract}

This study, which examines the relationship between Imam Hatip Secondary School (IHSS) students' perceptions of school climate and their engagement to school, aims to determine the perspectives of the students who enter a different academic structure after primary school. The opinions of the students studying at IHSS, which has a unique school climate and culture, are important. Although many researches have been conducted on school climate and school engagement for administrators and teachers, in this context, the study for IHSS students is scarce. The research was carried out in 2020 with the participation of 481 students studying at 11 IHSSs in Istanbul. "School Climate Scale" and "School Engagement Scale" were used in the research conducted by quantitative method. According to the research results; the school climate perceptions and school engagement of female students, students studying in lower grades, students residing with their parents, students who came to IHSS with their own preference and students who want to study at Imam Hatip High School or Science High School after IHSS was determined to be higher. In addition, it was found that there was a positive and significant relationship between students' perceptions of school climate and their engagement to school.

Key Words: Religious Education, Imam Hatip Secondary School, School Climate, School Engagement, School Culture

\section{Atıf İçin / Please Cite As:}

Koç, A. (2021). İmam hatip ortaokulu öğrencilerinin okul iklimi algıları ile okula bağlılıkları arasındaki ilişki. Manas Sosyal Arașturmalar Dergisi, 10(2), 798-812.

Geliş Tarihi / Received Date: 07.11.2020

Kabul Tarihi / Accepted Date: 08.02.2021

\footnotetext{
${ }^{1} \mathrm{Bu}$ araştırma, Yakın Doğu Üniversitesi Bilimsel Araştırmalar Etik Kurulu'nun 06.04.2020 tarih ve YDÜ/EB/2020/450 sayllı izni ile uygulanmıştır.

2 Dr. Ögretim Görevlisi - Hitit Üniversitesi, Çorum, Türkiye, ahmetkoc@hitit.edu.tr

iD ORCID: 0000-0001-6165-4401
} 


\section{Giriş}

Okullar, öğrencilerin günlük zamanlarının önemli kısmını geçirdikleri, hem akademik hem de sosyal etkinliklerde bulundukları, arkadaşlıklar kurdukları ve tam gelişme çağlarında kimliklerinin oluştuğu mekânlardır. Bu mekânlarda öğrencilerin kendilerini huzurlu, mutlu ve güvende hissetmeleri, akademik başarrları kadar sosyal gelişimleri için de oldukça önemlidir (Tong, Reynolds, Lee ve Liu, 2019, s. 509). Çünkü öğrenciler okulda kazandıkları yaşam tecrübelerini, sosyal hayata taşımakta ve beraberinde gelecekleri şekillenmektedir. Bu aşamada öğrencilerin kendilerini güvende hissettikleri ve mutlu oldukları bir okul ikliminin varlığı oldukça önemlidir (Gencer, 2019, s. 152).

Okul iklimi ve okula bağllılı arasındaki ilişkiyi inceleyen çeşitli araştırmalarda okul ortamının öğrencilerin okula bağlanması için oldukça önemli olduğu ve okul ikliminin öğrencilerin okula bağlllık düzeylerini etkileyen bir faktör olduğu ifade edilmektedir (Özgenel, Yılmaz ve Baydar, 2018, s. 98; TaşAkarsu, 2018, s. 61). Bu araştırma, İmam Hatip Ortaokulları (İHO)'nda öğrenim gören öğrencilerin okullarında algıladıkları okul iklimi ile okula bağlılıkları arasındaki ilişkiyi incelemek için yapılmıştır. Genellikle öğretmenlerin ve yöneticilerin görüsslerine dayalı olarak yapılan okul iklimi ve okula bağlllık konusundaki araştırmalardan farklı olarak bu araştırma, hem ilkokul eğitiminden sonra farklı bir ortamda eğitime başlayan ortaokul öğrencileriyle yapılmış olması açısından hem de kendine has iklim ve kültürüyle diğer ortaokullardan ayrılan İHO öğrencileriyle yapılmış olması açısından önemlidir.

\section{Kavramsal Çerçeve}

\section{Okul İklimi Kavramı ve İmam Hatip Okullarındaki Okul İklimi}

Okul iklimi; okul içindeki kişilerin davranışlarını biçimlendiren, okulun başka okullardan farklılaşmasını temin eden, okul bünyesindeki akademik başarı, iş güvenliği, huzur ve okula aidiyet gibi birçok değişkenden oluşan dinamikler bütünü şeklinde tarif edilmektedir (Şişman ve Uysal, 2015, s. 163). Okul iklimi, okuldaki kişilerin davranışlarından etkilendiği gibi, onların davranışlarını da etkilemektedir (Hoy, Tarter ve Kottkamp, 1991, s. 3). Başka bir deyişle okul içinde yer alan bütün paydaşlar okulun oluşturduğu atmosfer ile bütünleşmekte ve bu bütünlük okulun kimlik kazanmasını temin etmektedir. Bireyler için karakter hangi manaya geliyorsa, okullar için de iklim buna denk bir mana ifade etmektedir (Hoy ve Hannum, 1997, s. 292). Okul ikliminin olumlu olmas1, öğrencilerin akademik başarıya verdikleri önemin artmasını, arkadaşları, öğretmenleri ve okuldaki diğer kişilerle olumlu ilişkiler geliştirmelerini, okul kurallarına daha çok uyum göstermelerini, güvenlik konusuna dikkat etmelerini ve ailelerin okula daha çok katılım göstermelerini sağlamaktadır (Dönmez ve Taylı, 2018, s. 3).

İmam Hatip okullarını anlatırken kökleri Osmanlı Devletinin son dönemlerine kadar uzanan, sosyal, beşeri, fen ilimleri ile beraber İslami ilimleri tek bir program çatısı altında birleştiren, Türkiye’ye has bir model olduğu söylenebilir. Bu okullar, genel eğitimle birlikte bireylerin dini, ahlaki ve manevi ihtiyaçlarını karşılama hususunda mühim bir rol üstlenmektedir (Aktaş, 2017, s. 343). İHO, diğer ortaokullarda seçmeli olarak okutulan din ile ilgili derslerin müfredatın bir parçası olarak okutulduğu okullardır. Bu okullarda verilen eğitim içeriğinin ve şeklinin bir neticesi olarak bu okullara has oluşan bir okul iklimi ve okul kültürü bulunmaktadır (DOGM, 2018, s. 67). İmam Hatip okullarının her biri hem kendine özgü bir okul kültürü meydana getirmiş hem de bir bütün olarak ülke genelinde müşterek bir İmam Hatip kültürünün oluşmasını sağlamışlardır. İmam Hatip okullarını diğer okullardan ayıran bu iklim ve kültür, milli ve manevi değerlerin derslerde ve etkinliklerde yoğun şekilde işlenmesinden kaynaklı olabilir (Erdem, 2017, s. 64).

\section{Okula Bağlılı Kavramı ve Okul İklimi ile İlişkisi}

Okula bağlanma kavramı, ögrencinin okula devam etmesi, okuldaki sosyal etkinliklere katılması ve akademik başarı için çabayı içeren (Karababa, Oral ve Dilmaç, 2018, s. 269) ve bir bütün olarak okul ve öğrenci ilişkilerini kapsayan bir terimdir (Libbey, 2004, s. 275). Okula bağlılık kavramı "davranışsal, bilişsel ve duyuşsal" şeklindeki üç boyuttan oluşmaktadır. Davranışsal boyut; kurallara uyma, zarar verici davranışlar yapmama, öğrenmeye iştirak, sportif, sosyal ve yönetimsel katk1 sağlama gibi okul içinde yapılan eğitim ve sosyal etkinliklerindeki gözlenebilen faaliyetleri ve davranışları kapsar. Bilişsel boyut; öğrencinin çetin ve karmaşık hususları öğrenme ile ilgili lazım olan çabayı harcamada heveskâr ve titiz oluşunu kapsar. Duyuşsal boyut ise kişinin okulda bulunanlara ve okuluna yönelik olumlu tepkisi, diğer bir ifadeyle, okuldaki aktivitelerden söz ederken olumlu duygularını, müspet düşüncelerini, meraklı, ilgili ve coşkulu tepkilerini göstermesi şeklinde ifade edilmektedir (Fredricks, Blumenfeld ve Paris, 2004, s. 60). 
Okul iklimi ile öğrencilerin okula bağlllıkları arasındaki ilişkiye bakıldığında, öğrencilerin algıladı̆̆ı okul ikliminin, okula bağlllıkları üzerinde belirgin bir etkiye sahip olduğu söylenebilir. Çünkü okula verilen değerin artması, okula olan bağlılığın da artmasını sağlamaktadır (Dönmez ve Taylı, 2018, s. 3). Ayrıca okul ikliminin unsurlarından olan arkadaş ve öğretmen desteğinin öğrencilerin okula bağlanmasında önemli bir etkisinin olduğu ifade edilmektedir (Karababa vd., 2018, s. 269). Çünkü okul ortamında kabul edildiğini hisseden ve destek gören bir öğrencinin okuluna bağlllı̆̆ daha yüksek olmaktadır (Atik ve Yerin-Güneri, 2016, s. 93). Olumlu bir okul ikliminin oluşabilmesi için öğretmenlerin ve idarecilerin öğrencilerle olumlu ilişkiler kurmaları ve öğrencileri desteklemeleri, öğrencilerin birbirleriyle güzel arkadaşlıklar kurmaları (Brown, 2019, s. 93), okulun fiziki koşullarının ve sosyal faaliyetlerinin yeterince olması gerektiği belirtilmektedir (Özdemir, Sezgin, Şirin, Karip ve Erkan, 2010, s. 215). Böylelikle öğrencilerin okul memnuniyetlerinin artacağı, okulu daha çok sevecekleri ve okula daha fazla bağlanabilecekleri belirtilmektedir (Tavşanlı, Oksal ve Birgül, 2016, s. 828). Tüm bu bilgiler sşığında, bir öğrencinin kendini okula ait hissetmesi, okulu sevmesi, ögretmen desteği ve ilgisi, iyi arkadaşlara sahip olması, akademik yönteme uyum sağlaması, etkili bir disiplin yönteminin varlığı gibi durumların tümünün okula bağlllğ̆ın belirleyicileri olduğu söylenebilir (Libbey, 2004, s. 277).

\section{Araştırmanın Önemi ve Amacı}

Türkiye'de okul iklimi ve okula bağllık konularının incelenmesi ile ilgili çalışmaların büyük kısmı okul yöneticileri ve öğretmenlerinin görüşlerine dayalıdır. Okullardaki iklim ve okula bağlılık durumunu yalnızca okul yöneticileri ve öğretmenlerin algılarıyla kısıtlamamak, öğrencilerin algılarını da göz önünde bulundurmak gerekmektedir. Bu bakımdan öğrencilerin okul iklimi ve okula bağılık ile ilgili algılarını değerlendirmeye yönelik bu çalışma önem arz etmektedir. Çünkü öğrencilerin gözünde okulların nasıl mekânlar olduklanı, ögrencilerin okula istekli bir biçimde gidip gitmedikleri, okulda mutlu olup olmadıkları, okula ve okul çalışanlarına yönelik hissetmiş oldukları duygular eğitimin tüm paydaşları için önemlidir (Dönmez ve Tayli, 2018, s. 2).

Ortaokul eğitimi, hem ilkokulun ardından farklı bir akademik yapıyı hem de öğrencilerin ergenlik dönemi değişimlerine uyum sürecini kapsayan bir döneme rastlamaktadır. Bu dönem öğrencilerinin algıladıkları okul ikliminin önemine yönelik benzer bir çalısma, ülkemiz gibi ortaokul eğitimini 5. sınıf düzeyinde başlatan Portekiz'de yapılmıştır (Coelho, Romão, Brás, Bear ve Prioste, 2020). 2012 y1lında uygulanmaya başlayan 4+4+4 sistemiyle birlikte nicel olarak artış gösteren İHO'da okuyan öğrenciler ise ilkokul eğitiminden farklı bir eğitim görmekle birlikte kendine has iklim ve kültürüyle diğer ortaokullardan da ayrılan bir eğitim kurumunda bu dönemlerini geçirmektedirler. Bu bakımdan İHO öğrencilerinin okul iklimi algılarının ve okul bağllıklarının incelenmesi bu alandaki önemli bir boşluğu dolduracaktır. Çünkü literatür taraması yapıldığında diğer ortaokul öğrencilerine yönelik okula bağlllıklarını ve okul iklimi algılarını belirlemeye yönelik çeşitli çalışmalar olsa da (Dönmez ve Taylı, 2018; Karababa vd., 2018; Özgenel vd., 2018; Taş-Akarsu, 2018; Tavşanlı vd., 2016) İHO öğrencilerine yönelik bir çalışmaya rastlanmamıştır. Ayrıca İHO ile ilgili; öğrencilerinin okula bağlllı̆̆ (Aktaş, 2017), öğrencilerinin okul motivasyonları (Çiftçi, 2019) ve örgüt kültürünün incelenmesi (Erdem, 2017) gibi müstakil çalışmalar olsa da İHO'daki okul iklimini ve öğrencilerinin okula bağlllı̆ı̆n beraberce inceleyen bir çalışmaya rastlanmamıştır.

$\mathrm{Bu}$ araştırmanın amacı, İHO'da öğrenim gören öğrencilerin okullarında algıladıkları okul iklimi ile okula bağlllıkları arasındaki ilişkinin tespit edilmesidir. Araştırmada öncelikle öğrencilerin okul iklimi algıları ile okula bağllık puanlarının çeşitli değisskenlere göre farklılaşıp farklılaşmadığı incelenmiştir. Daha sonra okul iklimi algıları ile okula bağlılıkları arasındaki ilişki düzeyi tespit edilmiştir. Bu kapsamda, aşağıdaki araştırma sorularına cevap aranmışır:

1. Cinsiyet değişkenine göre öğrencilerin okul iklimi algıları ve okula bağl1lıkları anlamlı düzeyde farklılaşmakta mıdır?

2. Sınıf düzeyi değişkenine göre öğrencilerin okul iklimi algıları ve okula bağlllıkları anlamlı düzeyde farklılaşmakta mıdır?

3. Okul döneminde ikamet ettikleri yer değişkenine göre öğrencilerin okul iklimi algıları ve okula bağllıkları anlamlı düzeyde farklılaşmakta mıdır?

4. Okul tercihinde etkili olan kişi/kişiler değişkenine göre öğrencilerin okul iklimi algıları ve okula bağllikkları anlamlı düzeyde farklılaşmakta mıdır? 
5. Öğrencilerin ortaokuldan sonra gitmek istedikleri liseye göre öğrencilerin okul iklimi algıları ve okula bağllıkları anlamlı düzeyde farklılaşmakta mıdır?

6. Öğrencilerin okul iklimi algıları ile okula bağlılıkları arasında anlamlı bir ilişki var mıdır?

\section{Yöntem}

\section{Araştırma Modeli}

Araştırma, nicel araştırma yöntemine göre gerçekleştirilmiştir. Araştırma konusu olan İHO öğrencilerine yönelik karşılaştırma türü ilişkisel tarama yolu ile durum tespiti yapılmışır. Tarama modeli geçmişteki veya hâlihazırdaki durumu mevcut haliyle ortaya koyan araştırma modelleridir (Büyüköztürk, Kılıç-Çakmak, Erkan-Akgün, Karadeniz ve Demirel, 2019, s. 14). Araștırmada demografik değişkenler (cinsiyet, sınıf düzeyi ve ikamet durumu), öznel bağımsız değiş̧kenler (okul tercihinde etkili kişi/kişiler ve okumak istediği lise) ve iki ölçek (okul iklimi ve okul bağlılığı) kullanılmıştır.

\section{Evren - Örneklem}

Çalışmanın evrenini İstanbul'da okuyan İHO öğrencileri oluşturmaktadır. İstanbul genelinde 150 binden biraz fazla İHO öğrencisi bulunmaktadır. Örneklem hesaplanması amacıyla \% 95 güven düzeyi ve \% 5 hata payı dikkate alınarak yapılan işlem sonucunda, bu çalışma için evreni temsil edecek olan minimum örneklem sayısının 383 olarak hesaplanmıştır (Büyüköztürk vd., 2019, s. 98). Ortaya çıkan bu sonuca bakılarak, araştırmadaki 481 birimden meydana gelen örneklemin çalışma evrenini temsil gücü için yeterli olduğu ifade edilebilir. Araştırmada yer alan katılımcıların demografik özellikleri ile öznel bağımsız değişkenler Tablo 1'de gösterilmiştir:

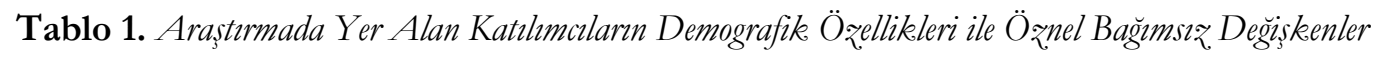

\begin{tabular}{|c|c|c|c|}
\hline Değişken & Düzey & $n$ & $\%$ \\
\hline \multirow{2}{*}{ Cinsiyet } & $\mathrm{K}_{12}$ & 271 & 56,3 \\
\hline & Erkek & 210 & 43,7 \\
\hline \multirow{4}{*}{ Sınıf Düzeyi } & 5. sinif & 96 & 20,0 \\
\hline & 6. sinif & 184 & 38,2 \\
\hline & 7. sinif & 100 & 20,8 \\
\hline & 8. $\sin 1 f$ & 101 & 21,0 \\
\hline \multirow{2}{*}{ İkamet Yeri } & Ailesinin yanında & 427 & 88,8 \\
\hline & Yurt/Kurs/Pansiyon & 54 & 11,2 \\
\hline \multirow{3}{*}{$\begin{array}{l}\text { Okul Tercihinde Etkili } \\
\text { Olan Kişi / Kişiler }\end{array}$} & Kendisi & 260 & 54,1 \\
\hline & Anne-babası & 186 & 38,7 \\
\hline & Diğer & 35 & 7,2 \\
\hline \multirow{6}{*}{$\begin{array}{l}\text { Okumak İstediği } \\
\text { Lise Türü }\end{array}$} & Henüz bir fikrim yok & 217 & 45,1 \\
\hline & Fen Lisesi & 100 & 20,8 \\
\hline & İmam Hatip Lisesi & 69 & 14,3 \\
\hline & Anadolu Lisesi & 60 & 12,5 \\
\hline & Meslek Lisesi & 14 & 2,9 \\
\hline & Diğer & 21 & 4,4 \\
\hline
\end{tabular}

Katılımcıların görüşlerinin çok farklı açlardan analiz edilebilmesi için araştırmada demografik özellikler geniş tutulmuştur. Öğrencilerin cinsiyet durumuna bakıldığında birbirine yakın sayıda oldukları, sınıf düzeylerine bakıldığında 6.sınıf düzeyinde bir miktar yoğunlaşma görülse de diğer sınıflar düzeyinde dengeli bir dağıllımdan söz edilebilir. Araştırmaya katılan öğrencilerin büyük çoğunluğunun $(\% 88,8)$ aileleriyle birlikte kalıyor olmaları hafızlık projesi kapsamındaki İHO’ların genel İHO’lar arasındaki yüzdesiyle uyumludur (DOGM, 2020, s. 1-7). İlkokuldan sonra okuyacakları ortaokulun seçiminde kimin etkili olduğu sorusu öğrencilere sorulduğunda yarıdan biraz fazlası $(\% 54,1)$ kendi tercihleri olduğunu, yarıya yakını $(\% 38,7)$ bu tercihte anne-babasının etkili olduğunu ve çok az bir kısmı $(\% 7,2)$ ise arkadaş veya ilkokul öğretmeni gibi kişilerin tavsiyesinin etkili olduğunu belirtmişlerdir. Bu bilgi literatürdeki bilgilerle uyumludur. İHO öğrencilerini okul motivasyonları hakkında yapılan bir çalışmada öğrencilerin yarısının $(50,8)$ İHO'yu kendisinin tercih ettiği, \%24,4’ünün ailesinin isteğiyle İHO'ya gittiği ve \%24,8’nin diğer sebeplerle İHO'da okuduğu sonucuna ulaşılmıștır (Çiftçi, 2019, s. 49). 2019 yllında yapılan iki ayrı çalışmada da İHO öğrencilerinin büyük kısmının (sırasıyla \%75,8 ve \%88,4) kendi istekleriyle okullarını tercih ettikleri ifade edilmiştir (Erkan, 2019, s. 74; Ünaldı, 2019, s. 51). 


\section{Veri Toplama Araçları}

Okul İklimi Ölçĕgi. Bu araştırmada kullanılan ölçeklerden biri Emmons ve arkadaşları tarafindan 2005 ylında geliştirilen, Atik ve Yerin-Güneri tarafından 2016 yllında Türkçe’ye uyarlaması yapılan "Okul İklimi Ölçeği”dir. Faktör analizi neticesinde, ölçeğin Türkçe Formu 36 madde ve "adalet, düzen ve disiplin, veli katılımı, kaynakların paylaşımı, öğrencilerin kişilerarası ilişkileri ve öğrenci-öğretmen ilişkileri” şeklindeki altı alt boyuttan meydana gelmektedir. Ölçeğin tamamı için Cronbach alfa değerleri $0,89 \mathrm{iken}$, alt boyutları için 0,64 ile 0,88 arasındadır. Ölçeğin tümü için oldukça güvenilir, alt boyutları için güvenilir ifadesi kullanılabilir. Tüm ölçeğin test-tekrar test güvenirlik katsayıs1 $0,67(\mathrm{p}<.01)$ iken, alt boyutları için 0,50 ile $0,73(\mathrm{p}<.01)$ arasında değişmektedir (Atik ve Yerin-Güneri, 2016, s. 101).

Okul Bağgllı̆̆ Ölçĕği. Fredericks ve arkadaşları tarafından 2005 yılında geliştirilen ölçek, Ahmet Akın ve arkadaşları tarafindan 2013 yılında Türkçe'ye uyarlanmıştır. Çocukların ve ergenlerin okula bağlllık düzeylerini belirlemek amacıyla geliştirilen ölçek, 19 maddeden ve "davranışsal bağlllık, duygusal bağlllık ve bilişsel bağlılık" şeklindeki üç alt boyuttan oluşmaktadır. Ölçekten elde edilen yüksek puan, katıllımcının yüksek düzeyde okul bağlllğı olduğunu ortaya koymaktadır. Ölçeğin tamamı için Cronbach alfa değerleri 0,87 iken, alt boyutları için 0,77 ile 0,86 arasında değişmektedir. Ölçek için oldukça güvenilir ifadesi kullanılabilir. Doğrulayıcı faktör analizi neticesinde üç boyutlu modelin iyi uyum verdiği belirlenmiştir $\left(\mathrm{x}^{2}=289,67, \mathrm{sd}=142, \mathrm{p}<0.001, \mathrm{RMSEA}=.058, \mathrm{NFI}=.94, \mathrm{NNFI}=.96, \mathrm{CFI}=.97, \mathrm{IFI}=.97, \mathrm{RFI}=.93\right.$, GFI=.91, AGFI=.88 ve SRMR=.056). Ölçeğin test-tekrar test güvenirlik katsayıs1 ölçeğin bütünü için 0,78 , alt boyutları için 0,62 ile 0,82 arasında değişmektedir. Ölçeğin madde toplam test korelasyonlarının ise 0,26 ile 0,71 arasında değiştiği ve alt ve üst $\% 27^{\prime}$ lik grupların, madde puanlarının ortalamalarının karşılaştırılması için yapılan bağımsız t-testi sonuçlarının anlamlı olduğu bulunmuştur (Akın vd., 2013, s. 172).

\section{Verilerin Analizi}

Araştırma, 2020 yllında İstanbul'un Sancaktepe, Sultanbeyli, Kartal, Pendik ve Arnavutköy ilçelerindeki 11 İHO'da yapılmışır.

İstatistiksel analiz için SSPS 25.0 programından yararlanılmıştır. Öğrencilerin okul iklimi algıları ve okula bağll1ıklarının ölçülmesi amacıyla aritmetik ortalamalar elde edilmiştir. Okul bağlllı̆̆ ölçeğinde kullanılan beşli Likert Ölçeği beş eşit parçaya bölünerek; okul iklimi ölçeğinde kullanılan üçlü Likert Ölçeği ise üç eşit parçaya bölünerek her seçeneğe karşılık gelen puan aralığı belirlenmiştir. Çalışmada her alt probleme uygun istatistiksel yöntemler kullanılmıstır. Grup sayısı iki olan demografik faktörler arasındaki farkllıkları tespit etmek amacıyla t testi kullanılmıştır. Grup sayısı ikiden çok olan öğelerin ilk olarak sorulara verdikleri cevaplar bakımından homojen dağılıp dağılmadıklarını tespit etmek amacıyla Levene testi kullanılmışır. Homojen dağılan gruplarda Anova testi kullanılarak gruplar arasında farklılığın 0,05 (\%95) anlamlılık seviyesinde olup olmadığ1 incelenmiştir. Homojen dağıllım göstermeyen gruplarda ise farklılık testi olarak Anova testinin alternatifi olan Brown-Forsyth testi kullanılmıştır. Anlamlı farklılık tespit edilen gruplarda hangi grupların diğerlerinden ayrıştığını belirlemek amacıyla LSD testi uygulanmıştır.

\section{Ölçeklerin Güvenilirlik Analizi}

Araştırmada kullanılan ölçeklerin güvenirlik analiz sonuçları ve madde toplam korelasyonları Tablo 2'de sunulmuştur:

Tablo 2. Ölçeklerin Güvenilirlike Analiæi

\begin{tabular}{|c|c|c|c|c|}
\hline Ölçek & Faktör & $\begin{array}{c}\text { Madde } \\
\text { Say1s1 } \\
\end{array}$ & $\begin{array}{c}\text { Cronbach's } \\
\text { Alpha } \\
\end{array}$ & $\begin{array}{c}\text { Madde Toplam } \\
\text { Korelasyonu } \\
\end{array}$ \\
\hline \multirow{6}{*}{ Okul İklimi Ölçeği } & Adalet & 4 & 0,63 & $0,55-0,33$ aras 1 \\
\hline & Düzen ve Disiplin & 7 & 0,77 & $0,65-0,35$ aras 1 \\
\hline & Veli Katılımı & 5 & 0,67 & $0,59-0,33$ aras 1 \\
\hline & Kaynakların Paylaşımı & 4 & 0,75 & $0,58-0,51$ aras 1 \\
\hline & Öğrencilerin Kişilerarası İlişkileri & 7 & 0,83 & $0,68-0,45$ aras 1 \\
\hline & Öğrenci-Öğretmen İlişkileri & 9 & 0,82 & $0,66-0,46$ aras 1 \\
\hline \multirow{3}{*}{ Okul Bağlllığ1 Ölçeği } & Davranışsal bağllilık & 5 & 0,52 & $0,43-0,29$ aras 1 \\
\hline & Duygusal bağll11k & 6 & 0,80 & $0,70-0,40$ aras 1 \\
\hline & Bilişsel bağlllık & 8 & 0,77 & $0,58-0,40$ aras 1 \\
\hline
\end{tabular}


Her iki ölçek için yapılan güvenilirlik analizinde Cronbach alfa değerleri; okul iklimi ölçeğinin tamamı için 0,90 , alt boyutları için 0,63 ile 0,83 arasında değişmektedir. Ölçeğin madde toplam korelasyonları 0,33 ile 0,68 arasındadır. Okul bağıllığ ölçeğinin tamamı için 0,85 , alt boyutları için 0,53 ile 0,80 arasında değişmektedir. Ölçeğin madde toplam korelasyonları ise 0,29 ile 0,70 arasındadır. Her iki ölçeğin tamamı için "oldukça güvenilir ölçek" ifadesi, alt boyutları için ise genel olarak "güvenilir ölçek" ifadesi kullanılabilir. Bu sonuçlar her iki ölçeğin araştırmada geçerli ve güvenilir bir ölçme aracı olarak kullanılabileceğini göstermektedir.

\section{Bulgular}

İHO öğrencilerinin okul iklimi algiları ve okula bağllık durumları belirlemek için yapılan analizler tablolar halinde verilmiş ve ardından literatürdeki sonuçlarla karşılaştırılmıştır. Her iki ölçeğin Skewness: 0,358 ve Kurtosis:- 0,044 puanlarının $-1,5<X<+1,5$ aralığında olduğu, buna göre verilerin normal dağılım gösterdiği ve parametrik testlerin uygulanabileceği söylenebilir (Büyüköztürk, 2020, s. 183).

\section{Öğrencilerin Cinsiyetlerine Göre Oku1 İklimi Algıları ve Okula Bağlılık Durumları}

Öğrencilerin cinsiyetlerine göre okul iklimi algıları ve okula bağll11k durumları Tablo 3’te verilmiştir:

Tablo 3. Cinsiyet Değişkenine Göre Öğrencilerin Okul İklimi Algzları ve Okula Bağhlıklarn

\begin{tabular}{|c|c|c|c|c|c|c|c|}
\hline Ölçek & Faktör & Cinsiyet & $n$ & $\overline{\bar{X}}$ & $S D$ & $t$ & $p$ \\
\hline \multirow{12}{*}{$\begin{array}{l}\text { Okul İklimi } \\
\text { Ölçeği }\end{array}$} & \multirow{2}{*}{ Adalet } & $\mathrm{K} 1 \mathrm{z}$ & 271 & 2,41 & 0,54 & \multirow{2}{*}{.998} & \multirow{2}{*}{.319} \\
\hline & & Erkek & 210 & 2,36 & 0,52 & & \\
\hline & \multirow{2}{*}{ Düzen ve Disiplin } & $\mathrm{K}_{12}$ & 271 & 2,24 & 0,52 & \multirow{2}{*}{8,667} & \multirow{2}{*}{$.000^{* *}$} \\
\hline & & Erkek & 210 & 1,84 & 0,49 & & \\
\hline & \multirow{2}{*}{ Veli Katılımı } & $\mathrm{K}_{1 z}$ & 271 & 1,73 & 0,54 & \multirow{2}{*}{$-1,964$} & \multirow{2}{*}{.050} \\
\hline & & Erkek & 210 & 1,83 & 0,54 & & \\
\hline & \multirow{2}{*}{ Kaynakların Paylaşımı } & $\mathrm{K}_{12}$ & 271 & 2,06 & 0,65 & \multirow{2}{*}{-.702} & \multirow{2}{*}{.483} \\
\hline & & Erkek & 210 & 2,10 & 0,61 & & \\
\hline & \multirow{2}{*}{$\begin{array}{l}\text { Ö̈ğrencilerin } \\
\text { İlişkileri }\end{array}$} & $\mathrm{K}_{12}$ & 271 & 2,19 & 0,50 & \multirow{2}{*}{4,633} & \multirow{2}{*}{$.000 * *$} \\
\hline & & Erkek & 210 & 1,98 & 0,51 & & \\
\hline & \multirow{2}{*}{ Öğrenci-Öğretmen İlişkileri } & $\mathrm{K}_{1 z}$ & 271 & 2,63 & 0,38 & \multirow{2}{*}{.895} & \multirow{2}{*}{.371} \\
\hline & & Erkek & 210 & 2,60 & 0,42 & & \\
\hline \multirow{6}{*}{$\begin{array}{l}\text { Okula } \\
\text { Bağllilığ } \\
\text { Ölçeği }\end{array}$} & \multirow{2}{*}{ Duygusal Bağllilk } & $\mathrm{K}_{12}$ & 271 & 4,22 & 0,71 & \multirow{2}{*}{2,572} & \multirow{2}{*}{$.010^{*}$} \\
\hline & & Erkek & 210 & 4,04 & 0,78 & & \\
\hline & \multirow{2}{*}{ Davranışsal Bağlılık } & $\mathrm{K}_{12}$ & 271 & 4,44 & 0,52 & \multirow{2}{*}{2,602} & \multirow{2}{*}{$.010^{*}$} \\
\hline & & Erkek & 210 & 4,31 & 0,57 & & \\
\hline & \multirow{2}{*}{ Bilişsel Bağllilık } & $\mathrm{K}_{1 z}$ & 271 & 3,76 & 0,76 & \multirow{2}{*}{2,442} & \multirow{2}{*}{$.015^{*}$} \\
\hline & & Erkek & 210 & 3,58 & 0,78 & & \\
\hline
\end{tabular}

${ }^{* \mathrm{p}<}<.05 ;{ }^{* *} \mathrm{p}<.01$

Cinsiyet değişkenine göre öğrencilerin okul iklimi algılarına bakıldığında iki boyutta kız öğrenciler lehine anlamlı düzeyde farkllılk olduğu görülmektedir. Kız öğrenciler "düzen ve disiplin" boyutunu $\overline{\mathrm{X}}=2,24$ puanla değerlendirirken, erkek öğrenciler $\overline{\mathrm{X}}=1,84$ puanla değerlendirmişlerdir. "Öğrencilerin kişilerarası ilişkiler" boyutunu ise kı öğrenciler $\overline{\mathrm{X}}=2,19$ puanla değerlendirirken, erkek öğrenciler $\overline{\mathrm{X}}=1,98$ puanla değerlendirmişlerdir. Okula bağlllık puanları cinsiyet değişkenine göre değerlendirildiğinde her üç boyutta da kız öğrenciler lehine anlamlı düzeyde farkll11k olduğu görülmektedir. Kız öğrenciler "duygusal bağlll1k" boyutunu $\bar{X}=4,22$ puanla, erkek öğrenciler $\bar{X}=4,04$ puanla; "davranışsal bağlllı" boyutunu kız ögrenciler $\overline{\mathrm{X}}=4,44$ puanla, erkek öğrenciler $\overline{\mathrm{X}}=4,31$; "bilişsel bağlll1k" boyutunu ise kı öğrenciler $\overline{\mathrm{X}}=3,76$ puanla değerlendirirken, erkek öğrenciler $\overline{\mathrm{X}}=3,58$ puanla değerlendirmişlerdir. Elde edilen bulgulara bakıldığında, kız öğrencilerin okul iklimi algılarının ve okula bağlılıklarının, erkek öğrencilere göre daha yüksek olduğu görülmüştür. 


\section{Öğrencilerin Sınıflarına Göre Okul İklimi Alg1ları ve Okula Bağlılık Durumları}

Öğrencilerin sınıflarına göre okul iklimi algıları ve okula bağlllık durumları Tablo 4’te verilmiştir:

Tablo 4. Sinnf Değğskenine Göre Öğrencilerin Okul İklimi Algzlar ve Okula Bağhllıklar

\begin{tabular}{|c|c|c|c|c|c|c|}
\hline Faktör & Levene & $P$ & $A N O V A$ & $\begin{array}{l}\text { Brown- } \\
\text { Forsyth }\end{array}$ & $p$ & Farklilik Olan Siniflar \\
\hline Adalet & 6,892 & $.000^{* *}$ & - & 13,355 & $.000^{* *}$ & $5>6,7,8 ; 6>7 ; 8>7$ \\
\hline Düzen ve Disiplin & .728 & .535 & 18,617 & - & $.000 * *$ & $5>6,7,8 ; 6>7 ; 8>6,7$ \\
\hline Veli Katılımı & .824 & .481 & 1,167 & - & .322 & - \\
\hline Kaynakların Paylaşımı & .155 & .926 & 15,008 & - & $.000 * *$ & $5>6,7,8 ; 6>7 ; 8>7$ \\
\hline Öğrencilerin Kişilerarası & 2,288 & .078 & 15,375 & - & $.000 * *$ & $5>6,7,8 ; 6>7$ \\
\hline Öğrenci-Öğretmen İlişkisi & 10,526 & $.000^{* *}$ & - & 8,602 & $.000^{* *}$ & $5>6,7,8$ \\
\hline Duygusal Bağll1ık & 7,342 & $.000^{* *}$ & - & 17,208 & $.000^{* *}$ & $5>6,7,8$ \\
\hline Davranışsal Bağlılık & 3,279 & $.000^{* *}$ & - & 8,632 & $.000^{* *}$ & $5>6,7,8 ; 6>7,8 ; 7>8$ \\
\hline Bilişsel Bağl1lık & 2,501 & .059 & 3,131 & - & $.025^{*}$ & $5>6,7,8$ \\
\hline
\end{tabular}

Sınıf değişkenine göre öğrencilerin okul iklimi algilarına bakıldığında "veli katılımı" faktörü hariç diğer tüm faktörlerde gruplar arasında anlamlı düzeyde farklılık olduğu görülmektedir. Farklılığın hangi gruplar arasında olduğunu belirlemek için uygulanan LSD testi sonuçlarına göre "adalet" faktörünü 5.sınıflar $\overline{\mathrm{X}}=2,64$, 6.sinıflar $\overline{\mathrm{X}}=2,37$, 7.siniflar $\overline{\mathrm{X}}=2,18$, 8.siniflar $\overline{\mathrm{X}}=2,38$ puanla değerlendirmişler. "Düzen ve disiplin” boyutunu 5.siniflar $\overline{\mathrm{X}}=2,34$, 6.siniflar $\overline{\mathrm{X}}=2,00, \quad 7$.siniflar $\overline{\mathrm{X}}=1,82$, 8.siniflar $\overline{\mathrm{X}}=2,17$ puanla değerlendirmişler. "Kaynakların paylaşımı" boyutunu 5.sınıflar $\overline{\mathrm{X}}=2,40,6 . \sin ı$ flar $\overline{\mathrm{X}}=2,05,7$.sınıflar $\overline{\mathrm{X}}=1,82$, 8.sınıflar $\overline{\mathrm{X}}=2,07$ puanla değerlendirmişler. Bu üç boyutta 5 .sınıfların diğer tüm sınıflardan yüksek puan verdikleri, 7.sınıfların ise diğer tüm sinıflardan daha düşük puan verdikleri görülmektedir. "Öğrencilerin kişilerarası ilişkileri” boyutunu 5.sınıflar $\overline{\mathrm{X}}=2,37$, 6.sınıflar $\overline{\mathrm{X}}=2,10,7$.sınıflar $\overline{\mathrm{X}}=1,90$, 8.sınıflar $\overline{\mathrm{X}}=2,03$ puanla değerlendirmişler. Bu boyutta 5.sınıfların diğer tüm sınıflardan; 6.sınıfların ise 7.sınıflardan yüksek

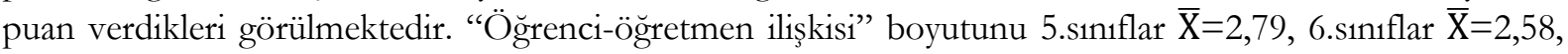
7.sınıflar $\overline{\mathrm{X}}=2,54$, 8.sınıflar $\overline{\mathrm{X}}=2,61$ puanla değerlendirmişler. Bu boyutta 5.sınıfların diğer tüm sınıflardan yüksek puan verdikleri görülmektedir. Okul bağlllı̆̆1 ölçeğinin "duygusal bağlllık" boyutunu 5.sinıflar $\overline{\mathrm{X}}=4,59$, 6.siniflar $\overline{\mathrm{X}}=4,06$, 7.sinfflar $\overline{\mathrm{X}}=3,95$, 8.siniflar $\overline{\mathrm{X}}=4,06$ puanla değerlendirmişler. Bu boyutta 5.sınıfların diğer tüm sınıflardan yüksek puan verdikleri görülmektedir. "Davranışsal bağlllık" boyutunu 5.siniflar $\overline{\mathrm{X}}=4,59$, 6.siniflar $\overline{\mathrm{X}}=4,40$, 7.sinıflar $\overline{\mathrm{X}}=4,27$, 8.sinıflar $\overline{\mathrm{X}}=4,26$ puanla değerlendirmişler. $\mathrm{Bu}$ boyutta $5 . s ı n ı f l a r ı n$ diğer tüm sınıflardan yüksek puan verdikleri, 8 .sınıfların ise diğer tüm sınıflardan daha düşük puan verdikleri görülmektedir. "Bilişsel bağllilk" boyutunu 5.sınıflar $\overline{\mathrm{X}}=3,88$, 6.sınıflar $\overline{\mathrm{X}}=3,60$, 7.sınıflar $\overline{\mathrm{X}}=3,63$, 8.sınıflar $\overline{\mathrm{X}}=3,69$ puanla değerlendirmişler. Bu boyutta 5.sınıfların diğer tüm sınıflardan yüksek puan verdikleri görülmektedir. Elde edilen bulgulara bakıldığında sınıf düzeyinin öğrencilerin okul iklimi algılarında ve okula bağlilıklarında anlamlı farklılık oluşturduğu, genel anlamda 5.sınıfların en yüksek olumlu iklim algisına sahip oldukları, 7.sınıf düzeyinde en düşük seviyeye geldiği ve 8 .sınıfta yeniden yükselmeye başladığı görülmektedir. Okula bağlılık durumunda ise 5.sınıflar düzeyinde okula bağl1lığın en yüksek seviyede olduğu ve sınıf düzeyi arttıkça öğrencilerin okula bağllıklarının azaldığı görülmüştür.

\section{Öğrencilerin İkamet Ettikleri Yere Göre Okul İklimi Algıları ve Okula Bağlılık Durumları}

Öğrencilerin ikamet ettikleri yer değişkenine göre okul iklimi algıları ve okula bağlılık durumları Tablo 5’te verilmiştir: 
Tablo 5. İkamet Durumu Değişkenine Göre Öğrencilerin Okul İklimi Algular ve Okula Bağhlıkları

\begin{tabular}{|c|c|c|c|c|c|c|c|}
\hline Ölçek & Faktör & Íkamet & $\mathrm{n}$ & $\bar{X}$ & $S D$ & $t$ & $p$ \\
\hline \multirow{12}{*}{$\begin{array}{l}\text { Okul İklimi } \\
\text { Ölçeği }\end{array}$} & \multirow{2}{*}{ Adalet } & Aile & 427 & 2,39 & 0,53 & \multirow{2}{*}{.096} & \multirow{2}{*}{.924} \\
\hline & & Yurt/kurs & 54 & 2,38 & 0,51 & & \\
\hline & \multirow{2}{*}{ Düzen ve Disiplin } & Aile & 427 & 2,06 & 0,55 & \multirow{2}{*}{$-1,118$} & \multirow{2}{*}{.264} \\
\hline & & Yurt/kurs & 54 & 2,15 & 0,51 & & \\
\hline & \multirow{2}{*}{ Veli Katılımı } & Aile & 427 & 1,79 & 0,54 & \multirow{2}{*}{1,240} & \multirow{2}{*}{.216} \\
\hline & & Yurt/kurs & 54 & 1,69 & 0,54 & & \\
\hline & \multirow{2}{*}{ Kaynakların Paylaşımı } & Aile & 427 & 2,09 & 0,63 & \multirow{2}{*}{1,398} & \multirow{2}{*}{.163} \\
\hline & & Yurt/kurs & 54 & 1,96 & 0,64 & & \\
\hline & \multirow{2}{*}{ Öğrencilerin Kişilerarası İlişkileri } & Aile & 427 & 2,10 & 0,52 & \multirow{2}{*}{.368} & \multirow{2}{*}{.713} \\
\hline & & Yurt/kurs & 54 & 2,07 & 0,46 & & \\
\hline & \multirow{2}{*}{ Öğrenci-Ö̆ğretmen İlişkileri } & Aile & 427 & 2,64 & 0,38 & \multirow{2}{*}{2,231} & \multirow{2}{*}{$.029 *$} \\
\hline & & Yurt/kurs & 54 & 2,48 & 0,49 & & \\
\hline \multirow{6}{*}{$\begin{array}{l}\text { Okul Bağllllı̆g1 } \\
\text { Ölçeği }\end{array}$} & \multirow{2}{*}{ Duygusal Bağlllık } & Aile & 427 & 4,16 & 0,72 & \multirow{2}{*}{1,776} & \multirow{2}{*}{.082} \\
\hline & & Yurt/kurs & 54 & 3,93 & 0,92 & & \\
\hline & \multirow{2}{*}{ Davranışsal Bağlılık } & Aile & 427 & 4,40 & 0,52 & \multirow{2}{*}{1,800} & \multirow{2}{*}{.073} \\
\hline & & Yurt/kurs & 54 & 4,25 & 0,66 & & \\
\hline & \multirow{2}{*}{ Bilişsel Bağlılık } & Aile & 427 & 3,72 & 0,74 & \multirow{2}{*}{2,586} & \multirow{2}{*}{$.012^{*}$} \\
\hline & & Yurt/kurs & 54 & 3,37 & 0,95 & & \\
\hline
\end{tabular}

Öğrencilerin ikamet ettikleri yer değişkenine göre okul iklimi algıları Tablo 5’teki verilere göre incelendiğinde sadece "öğrenci-öğretmen ilişkileri" boyutunda ailesiyle birlikte kalan öğrenciler lehine anlamlı düzeyde bir farklılık olduğu görülmektedir. Kendi evinde kalan öğrenciler bu boyutu $\bar{X}=2,64$ puanla değerlendirirken, yurt/kurs/pansiyonda kalan öğrenciler ise $\overline{\mathrm{X}}=2,48$ puanla değerlendirmişlerdir. Okula bağlllık puanları ikamet değişkenine göre incelendiğinde sadece "bilişsel bağllılı" boyutunda ailesiyle birlikte kalan öğrenciler lehine anlamlı düzeyde bir farklılık olduğu görülmektedir. Kendi evinde kalan öğrenciler bu boyutu $\overline{\mathrm{X}}=3,72$ puanla değerlendirirken, yurt/kurs/pansiyonda kalan öğrenciler ise $\overline{\mathrm{X}}=3,37$ puanla değerlendirmişlerdir. Elde edilen bulgulara göre ikamet değişkeninin öğrencilerin okul iklimi algılarını ve okula bağlılıklarını birer boyutta değiştirdiği görülmektedir. "Öğrenci-öğretmen ilişkisi” ve "bilişsel bağlll1k" boyutlarında kendi evlerinde anne-babalarıyla beraber kalan öğrencilerin olumlu okul iklimi algılarının ve okula bağlllıklarının yurt/kurs/pansiyonda kalan öğrencilere göre daha yüksek olduğu tespit edilmiştir.

\section{Öğrencilerin İHO’yu Tercih Ederken Karar Vermelerinde Etkili Olan Kişi/Kişilere Göre Okul İklimi Algıları ve Okula Bağlılık Durumları}

Öğrencilerin İHO’yu tercih ederken karar vermelerinde etkili olan kişi/kişiler değişkenine göre okul iklimi algıları ve okula bağlllık durumları Tablo 6'da verilmiştir:

Tablo 6. Okul Tercibinde Etkili Olan Kişi/Kişilere Göre Öğrencilerin Okul İklimi Alguları ve Okula Bağlllıkları

\begin{tabular}{|c|c|c|c|c|c|c|}
\hline Faktör & Levene & $p$ & $A N O V A$ & Brown- & $p$ & Farklil1k Olan Gruplar \\
\hline Adalet & 3,816 & $.023^{*}$ & - & 3,587 & $.031 *$ & Kendi > Anne-baba \\
\hline Düzen ve Disiplin & 2,502 & .083 & 11,413 & - & $.000 * *$ & Kendi $>$ Anne-baba \\
\hline Veli Katılımı & 3,521 & $.030^{*}$ & - & 2,095 & .126 & - \\
\hline Kaynakların Paylaşımı & 2,660 & .071 & 3,784 & - & $.023^{*}$ & Kendi $>$ Anne-baba \\
\hline Öğrencilerin Kişilerarası & 1,529 & .218 & 5,289 & - & $.003 * *$ & Kendi $>$ Anne-baba \\
\hline Öğrenci-Öğretmen İlişkisi & 8,049 & $.000^{* *}$ & - & 5,325 & $.006^{* *}$ & Kendi $>$ Anne-baba \\
\hline Duygusal Bağlilik & 6,030 & $.003^{* *}$ & - & 10,905 & $.000 * *$ & Kendi > Anne-baba \\
\hline Davranışsal Bağlılık & 1,869 & .155 & 3,815 & - & $.023 *$ & Kendi $>$ Anne-baba \\
\hline Bilişsel Bağllilık & .240 & .787 & 4,474 & - & $.012 *$ & Kendi $>$ Anne-baba \\
\hline
\end{tabular}

İHO’yu tercih ederken karar vermelerinde etkili olan kişi/kişiler değişkenine göre öğrencilerin okul iklimi algilarına incelendiğinde "veli katılımı" faktörü hariç diğer tüm faktörlerde gruplar arasında anlamlı seviyede farklılık olduğu belirlenmiştir. Farklılığın kaynağını tespit etmek için yapılan LSD testi neticesine göre "adalet" faktörünü okulu kendi tercih edenler $\overline{\mathrm{X}}=2,45$, okula anne-babasının isteğiyle gelenler $\overline{\mathrm{X}}=2,30$, okula diğer sebeplerle gelenler $\overline{\mathrm{X}}=2,38$ puanla değerlendirmişler. "Düzen ve disiplin" boyutunu okulu 
kendi tercih edenler $\overline{\mathrm{X}}=2,15$, okula anne-babasının isteğiyle gelenler $\overline{\mathrm{X}}=1,92$, okula diğer sebeplerle gelenler $\bar{X}=2,20$ puanla değerlendirmişler. "Kaynakların paylaşımı" boyutunda okulu kendi tercih edenler $\overline{\mathrm{X}}=2,14$, okula anne-babasının isteğiyle gelenler $\overline{\mathrm{X}}=1,98$, okula diğer sebeplerle gelenler $\overline{\mathrm{X}}=2,10$ puanla değerlendirmişler. "Öğrencilerin kişilerarası ilişkileri”" boyutunda okulu kendi tercih edenler $\bar{X}=2,16$, okula anne-babasının isteğiyle gelenler $\overline{\mathrm{X}}=2,00$, okula diğer sebeplerle gelenler $\overline{\mathrm{X}}=2,17$ puanla değerlendirmişler. “Öğrenci-öğretmen ilişkileri” boyutunda okulu kendi tercih edenler $\overline{\mathrm{X}}=2,68$, okula anne-babasının isteğiyle gelenler $\overline{\mathrm{X}}=2,54$, okula diğer sebeplerle gelenler $\overline{\mathrm{X}}=2,62$ puanla değerlendirmişler. Bu sonuçlara göre okula kendi tercihiyle gelen öğrencilerin olumlu okul iklimi algısının anne-babasının isteğiyle gelenlerden anlamlı düzeyde yüksek olduğu görülmektedir. Okul bağlllığı ölçeğinin "duygusal bağlllık” boyutunu okulu kendi tercih edenler $\bar{X}=4,29$, okula anne-babasının isteğiyle gelenler $\bar{X}=3,92$, okula diğer sebeplerle gelenler $\overline{\mathrm{X}}=4,19$ puanla değerlendirmişler. "Davranışsal bağlllık" boyutunu okulu kendi tercih edenler $\overline{\mathrm{X}}=4,43$, okula anne-babasının isteğiyle gelenler $\overline{\mathrm{X}}=4,29$, okula diğer sebeplerle gelenler $\overline{\mathrm{X}}=4,47$ puanla değerlendirmişler. "Bilişsel bağlllık" boyutunu okulu kendi tercih edenler $\overline{\mathrm{X}}=3,74$, okula anne-babasının isteğiyle gelenler $\overline{\mathrm{X}}=3,56$, okula diğer sebeplerle gelenler $\overline{\mathrm{X}}=3,88$ puanla değerlendirmişler. Bu sonuçlara göre okula kendi tercihiyle gelen öğrencilerin okula bağlılıklarının diğer gruplardan daha yüksek olduğu; anne-babasının isteğiyle gelenlerin ise diğer gruplardan daha düşük olduğu görülmektedir. Elde edilen bulgulara bakıldığında İHO tercihinde etkili olan kişi/kişiler değişkeninin öğrencilerin okul iklimi algılarında ve okula bağllliklarında anlamlı farklılık oluşturduğu, kendi tercihleriyle İHO'ya gelen ögrencilerin okul iklimi algılarının ve okula bağlliklarının diğer gruplardan daha yüksek olduğu görülmektedir.

\section{Öğrencilerin İHO’yu Bitirdikten Sonra Gitmek İstedikleri Liseye Göre Okul İklimi Algıları ve Okula Bağlılık Durumları}

İHO'yu bitirdikten sonra gitmek istedikleri lise değişkenine göre öğrencilerin okul iklimi algıları ve okula bağll11k durumları Tablo 7'de verilmiştir:

Tablo 7. Gitmek İstedikleri Lise Değiskeenine Göre Ögrrencilerin Okul İklimi Algzlar ve Okula Bağhlıklar

\begin{tabular}{|c|c|c|c|c|c|c|}
\hline Faktör & Levene & $p$ & $A N O V A$ & $\begin{array}{l}\text { Brown- } \\
\text { Forsyth }\end{array}$ & $p$ & $\begin{array}{c}\text { Farkluluk Olan } \\
\text { Gruplar }\end{array}$ \\
\hline Adalet & 2,054 & .070 & 1,490 & - & .192 & - \\
\hline Düzen ve Disiplin & .754 & .584 & 4,017 & - & $.001^{* *}$ & $\begin{array}{c}\text { Tüm gruplar > } \\
\text { Meslek lisesi }\end{array}$ \\
\hline Veli Katılımı & .571 & .722 & .516 & - & .764 & - \\
\hline Kaynakların Paylaşımı & .212 & .957 & 1987 & - & .079 & - \\
\hline Öğrencilerin Kişilerarası İlişkileri & 1,140 & .338 & 2,908 & - & $.013 *$ & $\begin{array}{c}\text { Tüm gruplar > } \\
\text { Meslek lisesi }\end{array}$ \\
\hline Öğrenci-Öğretmen İlişkisi & 6,107 & $.000 * *$ & - & 3,499 & $.007 * *$ & $\begin{array}{c}\mathrm{HFY}>\mathrm{AL}, \mathrm{ML}, \mathrm{D} \\
\dot{\mathrm{I} H L}>\mathrm{AL}, \mathrm{ML}, \mathrm{D} \\
\mathrm{FL}>\mathrm{AL}, \mathrm{ML}, \mathrm{D} \\
\mathrm{AL}>\mathrm{ML}\end{array}$ \\
\hline Duygusal Bağlılık & 3,792 & $.002 * *$ & - & 4,982 & $.001 * *$ & $\begin{array}{c}\mathrm{HFY}>\mathrm{ML}, \mathrm{D} \\
\dot{\mathrm{I} H L}>\mathrm{ML}, \mathrm{D} \\
\mathrm{FL}>\mathrm{AL}, \mathrm{ML}, \mathrm{D} \\
\mathrm{AL}>\mathrm{ML}, \mathrm{D}\end{array}$ \\
\hline Davranışsal Bağlılık & 2,787 & $.017^{*}$ & - & 2,253 & .056 & - \\
\hline Bilişsel Bağlılık & 3,779 & $.002^{* *}$ & - & 3,548 & $.007 * *$ & $\begin{array}{c}\mathrm{HFY}>\mathrm{ML} \\
\dot{\mathrm{I} H L}>\mathrm{HFY}, \mathrm{ML} \\
\mathrm{FL}>\mathrm{HFY}, \mathrm{ML} \\
\mathrm{AL}>\mathrm{ML}\end{array}$ \\
\hline
\end{tabular}

${ }^{*} \mathrm{p}<.05 ;{ }^{*}{ }_{\mathrm{p}}<.01$

HFY: Henüz fikrim yok, İHL: İmam hatip lisesi, FL: Fen lisesi, AL: Anadolu lisesi, ML: Meslek lisesi, D: Diğer 
İHO'yu bitirdikten sonra gitmek istedikleri lise değişkenine göre öğrencilerin okul iklimi algılarına bakıldığında "adalet", "veli katılımı", "kaynakların paylaşımı" faktörlerinde gruplar arasında anlamlı seviyede farklılık olmadığı belirlenmiştir. "Düzen ve disiplin" faktörünü henüz fikri olmayan öğrenciler $\overline{\mathrm{X}}=2,11$, tercihi İHL olanlar $\overline{\mathrm{X}}=2,10$, tercihi Fen lisesi olanlar $\overline{\mathrm{X}}=2,04$, tercihi Anadolu lisesi olanlar $\overline{\mathrm{X}}=2,09$, tercihi Meslek lisesi olanlar $\overline{\mathrm{X}}=1,46$, diğer okulları tercih edenler ise $\overline{\mathrm{X}}=1,98$ puanla değerlendirmişlerdir. “Öğrencilerin kişilerarası ilişkileri” faktörünü henüz fikri olmayan öğrenciler $\bar{X}=2,17$, tercihi İHL olanlar $\overline{\mathrm{X}}=2,07$, tercihi Fen lisesi olanlar $\overline{\mathrm{X}}=2,08$, tercihi Anadolu lisesi olanlar $\overline{\mathrm{X}}=2,05$, tercihi Meslek lisesi olanlar $\overline{\mathrm{X}}=1,72$, diğer okulları tercih edenler ise $\overline{\mathrm{X}}=1,94$ puanla değerlendirmişlerdir. Bu iki boyutta İHO'dan sonra meslek lisesine gitmeyi düşünenlerin diğer tüm gruplardan daha düşük puan verdikleri görülmektedir. “Öğrenci-öğretmen ilişkisi” faktörünü henüz fikri olmayan öğrenciler $\overline{\mathrm{X}}=2,65$, tercihi İHL olanlar $\overline{\mathrm{X}}=2,68$, tercihi Fen lisesi olanlar $\bar{X}=2,66$, tercihi Anadolu lisesi olanlar $\bar{X}=2,51$, tercihi Meslek lisesi olanlar $\bar{X}=2,21$, diğer okulları tercih edenler ise $\overline{\mathrm{X}}=2,47$ puanla değerlendirmişlerdir. Bu boyutta en yüksek puanı lise tercihi İHL olan öğrenciler verirken grupların kendi arasında anlamlı farklılıklar bulunmaktadır. Okul bağgllı̆̆1 ölçeği öğrencilerin gitmek istedikleri lise değişkenine göre değerlendirildiğinde "davranışsal bağllllk" boyutunda gruplar arasında anlamlı düzeyde farklılık olmadığı görülmektedir. "Duygusal bağlllık" faktörünü henüz fikri olmayan öğrenciler $\overline{\mathrm{X}}=4,16$, tercihi İHL olanlar $\overline{\mathrm{X}}=4,22$, tercihi Fen lisesi olanlar $\overline{\mathrm{X}}=4,30$, tercihi Anadolu lisesi olanlar $\overline{\mathrm{X}}=4,04$, tercihi Meslek lisesi olanlar $\overline{\mathrm{X}}=3,32$, diğer okulları tercih edenler ise $\overline{\mathrm{X}}=3,67$ puanla değerlendirmişlerdir. "Bilişsel bağlll1k" faktörünü henüz fikri olmayan öğrenciler $\overline{\mathrm{X}}=3,58$, tercihi İHL olanlar $\overline{\mathrm{X}}=3,79$, tercihi Fen lisesi olanlar $\overline{\mathrm{X}}=3,91$, tercihi Anadolu lisesi olanlar $\overline{\mathrm{X}}=3,70$, tercihi Meslek lisesi olanlar $\overline{\mathrm{X}}=3,16$, diğer okulları tercih edenler ise $\overline{\mathrm{X}}=3,57$ puanla değerlendirmişlerdir. Bu iki boyutta grupların kendi aralarında anlamlı düzeyde farklılıklar olduğu tespit edilmiştir. Elde edilen bulgulara göre İHO'da okuyan öğrencilerin lise eğitimini devam etmek istedikleri okullara göre okul iklimi algılarının ve okula bağlılıklarının anlamlı şekilde farklılaştı̆̆ı görülmektedir. Özellikle lise eğitimini Fen Lisesi ve İHL'de devam ettirmek isteyen öğrencilerin diğer liselerde okumak isteyen öğrencilere göre olumlu okul iklimi algılarının ve okula bağllıklarının daha yüksek olduğu ifade edilebilir. Meslek lisesine gitmek isteyen öğrencilerin ise gruplar arasında en düşük seviyede olumlu okul iklimi algisı ve okula bağl1l1k yaşadıkları görülmektedir.

\section{Okul İklimi ve Okula Bağlılık Ölçekleri Arasındaki İlişki}

İHO'da okuyan öğrencilerin görüşlerine göre okul iklimi ve okul bağlllı̆̆ı ölçeklerinin birbirleri arasında ilişki olup olmadığını belirlemek için yapılan korelasyon sonuçları Tablo 8'de sunulmuştur:

Tablo 8. Ölçekler Arasindaki İliskiye Ait Korelasyon

\begin{tabular}{llcc}
\hline Ölçek & & Okul İklimi Ölçeği & Okul Bağlllı̆ğ Ölçĕgi \\
\hline \multirow{2}{*}{ Okul İklimi Ölçeği } & Pearson Correlation & 1 &, $530^{* *}$ \\
\cline { 2 - 4 } & Sig. (2-tailed) & & 0,000 \\
\hline \multirow{2}{*}{ Okul Bağlllı̆̆1 Ölçeği } & Pearson Correlation &, $530^{* *}$ & 1 \\
\cline { 2 - 3 } & Sig. (2-tailed) & 0,000 & \\
\hline ** $<.01$ & &
\end{tabular}

Tablo 8'de verilen korelasyon sonuçlarına göre okul iklimi ile okul bağlllığı ölçekleri arasında ise pozitif ve anlamlı bir ilişki olduğu ( $r=.530)$ görülmektedir (Büyüköztürk, 2020, s. 34). Buna göre öğrencilerin olumlu okul iklimi algıları arttıkça okula olan bağlllıklarının da arttığını söylemek mümkündür. Determinasyon katsayısı $\left(\mathrm{r}^{2}=0,28\right)$ dikkate alındığında okula bağlanmadaki toplam değişkenliğim $\% 28$ 'sinin ögrencilerin okula aidiyetlerinden kaynaklandığı söylenebilir. Sonuç olarak okul iklimi algısı yüksek olan öğrencilerin okula bağllılılarının da yüksek olduğu ifade edilebilir.

\section{Tartışma, Sonuç ve Öneriler}

İmam Hatip Ortaokul öğrencilerinin okul iklimi algıları ile okula bağllıkları arasındaki ilişkinin incelendiği bu araştırmada şu sonuçlara ulaşılmıştır:

Cinsiyet değişkenine göre sonuçlara bakıldığında kız öğrencilerin okul iklimi ölçeğinin iki boyutunu ve okul bağlılığı ölçeğinin tüm boyutlarını erkek öğrencilere göre anlamlı düzeyde yüksek puanla değerlendirdikleri belirlenmiştir. Özellikle kız öğrencilerin okul iklimi ölçeğinin "düzen ve disiplin” ve "öğrencilerin kişilerarası ilişkiler" boyutlarındaki yüksek algı düzeyleri dikkate alındığında okula ve eğitime daha çok motive oldukları ve okul içindeki sorunlarını çözmede iletişimi daha güçlü kullandıkları 
söylenebilir. Kız öğrencilerin okul iklimi algılarının ve okula bağlılıklarının, erkek öğrencilere göre daha yüksek olmasının bir diğer sebebi olarak; ortaokul öğrencilerinin yaş itibariyle ergenlik döneminin ilk yıllarını yaşıyor olmaları, pek çok değişikliğin ve zorlukların meydana geldiği bu dönem özelliklerinin okul yaşamına yansımasına yol açabilir. Bu aşamada kız öğrencilerin kendi aralarındaki ilişkilerle akran desteği ve öğrenci-öğretmen ilişkisi ile de yetişkin desteğine daha çok sahip olmalarının okul iklimi algılarını ve okula bağlılıklarını arttırdığı ifade edilebilir. Literatüre bakıldığında ortaokul öğrencileriyle yapılan bir çalışmada kız öğrencilerin erkeklere göre daha olumlu okul iklimi algısına sahip oldukları (Özgenel vd., 2018, s. 94), kızların erkeklere göre aktivitelere katılmada daha istekli oldukları, okulu daha fazla benimsedikleri, okuldaki olumlu firsatları daha çok fark ettikleri, bunun sonucunda daha olumlu bir okul iklimi algisına sahip oldukları belirtilmiştir (Dönmez, 2016, s. 55). Çünkü öğretmenlerin öğrencileriyle sevgi ve saygiya dayalı bir iletişim içinde olması ile öğrencilerin arkadaşlarıyla iyi ilişkiler kurmasının onların hem olumlu iklim algılarını yükselttiği (Çelebi ve Çopur, 2019, s. 807; Brown, 2019, s. 323; Tavşanlı vd., 2016, s. 836) hem de okula olan bağllıklarını arttırdığı belirtilmektedir (Kızıldağ, Demirtaş-Zorbaz ve Zorbaz, 2017, s. 113; Karababa vd., 2018, s. 274). Hem İHO hem de diğer ortaokul öğrencilerine yönelik yapılan başka çalışmalarda da kız öğrencilerin okula bağlılıklarının daha yüksek olduğu ortaya konmuştur (Aktaş, 2017, s. 349; Taş-Akarsu, 2018, s. 52). Farklı bir sonucun çıktığı araştırmalarda ise erkek öğrencilerin bağllık düzeylerinin kızlara göre daha yüksek olduğu (Onuk, 2017, s. 45), bunun sebebi olarak da erkek ögrencilerin karşlaştıkları okul içi sorunlara karşı daha fazla problem çözücü olmaları ifade edilmiştir (Dönmez, 2016, s. 57).

Sınıf düzeyine göre sonuçlara bakıldığında "veli katılımı" boyutu hariç her iki ölçeğin tüm boyutlarında sinıflar arasında anlamlı düzeyde farklılık olduğu belirlenmiştir. 5.sinıfların okul iklimi algilarının ve okula bağlllıklarının diğer sınıflara göre daha yüksek olduğu ve genel olarak üst sınıflara doğru her iki ölçek puanlarının anlamlı düzeyde düştüğü tespit edilmiştir. Bunun sebebi, ortaokul döneminde küçük yaştaki öğrencilerin öğrenmeye daha istekli olmaları, İHO’ya gelen öğrencilerin başlangıçtaki beklentilerine uygun olarak yüksek düzeyde okul iklimi algılarının ve okula bağllıklarının, sınıf seviyesi yükseldikçe akademik anlamda kaygı yaşamaları ve ergenlik dönemlerinde yaşadıkları psikolojik süreçlerin sonucunda düşmesi ile açıklanabilir. Ayrıca 5.sınıf düzeyinde en yüksek seviyedeki olumlu iklim algısının, 7.sınıf düzeyinde en düşük seviyeye geldiği ve 8.sınıfta yeniden yükselmeye başladığı görülmektedir. Okula bağll11k durumunda ise 5.sinıflar düzeyinde okula bağlllı̆̆ın en yüksek seviyede olduğu ve sinıf düzeyi arttıkça öğrencilerin okula bağlllıklarının azaldığı görülmüştür. Bu sonuçların sebebi olarak; çoğunluğu kendi tercihiyle İHO'ya gelen öğrencilerin başlangıçta yüksek olan olumlu okul iklimi algılarının, sınıf seviyesi yükseldikçe başarı odaklılık anlamında beklentilerinin tam olarak karşılanmaması, ortaokul geçişinde yaşanan sorunlar (Malone, Cornell ve Shukla, 2020, s. 301; Madjar ve Cohen-Malayev, 2016, s. 270) ve ergenlik dönemlerinde yaşadıkları psikolojik süreçlerin bir sonucu olarak zaman içinde düştüğu şeklinde açılanabilir. 8.sınıfta bir önceki sınıfa göre okul iklimi algısının kısmen yükselmesi ise bu öğrencilerin İHO'daki en üst sınıf olması sebebiyle okulu daha çok kabullenmesi ile açıklanabilir. Literatüre bakıldığında sınıf seviyesi yükseldikçe olumlu iklim algisının düştüğü (Dönmez, 2016, s. 48) ve okula bağlılıklarının azaldığ1 (Özgenel vd., 2018, s. 95), bunun sebebi olarak, 11-13 yaşları arası, öğrencilerin ögrenmeye daha hevesli oldukları, öğretmenleriyle daha iyi ilişki kurmak ve onları memnun etmek istedikleri bir dönem olduğu ifade edilmektedir (Aktaş, 2017, s. 344). Başka bir araştırmada, 5.sınıf düzeyindeki öğrencilerin ortaokula başlama yaşının küçüklüğü ve ilkokuldan farklı bir ortama uyum sağlayamaması gibi sebeplerle düşük olan okul iklimi algisı (Coelho vd., 2020, s. 188) bu araştırmanın sonuçlarıyla örtüşmemektedir. Çünkü bu araştırmada en yüksek okul iklimi algısına sahip sınıf düzeyi, 5.sınıf olmuştur. Farklı bir sonucun çıktığı başka bir araştırmada ise sınıf düzeyinin ortaokul öğrencilerinin okula bağlılıklarını değiştirmediği ortaya konulmuştur (Dönmez, 2016, s. 48).

Öğrencilerin ikamet durumlarına göre sonuçlar ele alındığında okul iklimi ölçeğinin bir boyutunu ve okul bağlliğı ölçeğinin bir boyutunu anne-babalarıyla beraber kalan öğrencilerin, yurt/kurs/pansiyonda kalan öğrencilere göre daha yüksek puanla değerlendirdikleri belirlenmiştir. Farklilğın "öğrenci-öğretmen ilişkisi" ve "bilişsel bağlılık" boyutlarında olduğu dikkate alındığında, ortaokul dönemindeki çocukların anne-babalarına oldukça bağlı oldukları, ailesinden uzakta kalan öğrencilerin derslere motive olmakta daha zorlandıkları ve daha fazla yetişkin (öğretmen) desteğine ihtiyaç duydukları söylenebilir. Anne-babalarıyla beraber kalan öğrencilerin okul iklimi ve okula bağlllık algilarının daha yüksek çıkmasının sebebi olarak ortaokul dönemindeki ergenlerin anne-babalarına bağlanmasının hala yüksek düzeyde olduğu söylenebilir (Topçu, 2019, s. 70). Hafızlık projesinin uygulandığı İHO'da okuyan öğrencilere yönelik yapılan iki ayrı çalışmada, ortaokul öğrencilerinin ailelerinden uzak kalmamaları önerisi getirilmiş, hafizlık yaparken ailesinden ayrı olan öğrencilerin kendisini derse vermesinin daha zor olduğu (Arslantaş, 2019, s. 55) ve bu 
yaş grubundaki öğrencilerin ailelerinden uzun süre uzak kalmalarının psikolojik ve gelişim süreçlerinde bazı sıkıntılara yol açabileceği (Yetimova, 2018, s. 135) belirtilmiştir.

Öğrencilerin İHO gelmelerinde etkili olan kişi/kişilere göre sonuçlara bakıldığında kendi isteğiyle İHO'da okuyan öğrencilerin olumlu iklim algılarının ve okula bağlılıklarının anne-babasının isteğiyle, arkadaş/öğretmen tavsiyesiyle gelen öğrencilerden anlamlı düzeyde yüksek olduğu tespit edilmiştir. Bunun sebebi, kendi isteğiyle İHO'ya gelen öğrencilerin okula ve eğitime yönelik içsel motivasyonlarının daha fazla olması ile açıklanabilir. Çünkü literatürde kendi isteğiyle okula gelen öğrencilerin okula daha kolay uyum sağlayabildiği, arkadaş ve öğretmen ilişkilerinde daha girişken olabildiği, akademik ve sosyal yönden gelişimi için daha az dış desteğe ihtiyaç hissedebildiği ifade edilmektedir (Koç, 2020a, s. 1484). Benzer bir bulgu İHO öğrencileriyle yapılan iki ayrı çalışmada ortaya konulmuş, araştırmaya katılan İHO öğrencilerinin büyük çoğunluğunun kendi istekleriyle okula geldikleri, bunun içsel bir motivasyon sağladığ1 belirtilmiştir (Erkan, 2019, s. 84). Ayrıca bu grubun okul motivasyon düzeylerinin, ailesinin isteğiyle kayıt yaptıranlardan daha yüksek olduğu ifade edilmiştir (Çiftçi, 2019, s. 68).

İHO'da okuyan öğrencilerin ortaokulu bitirdikten sonra okumak istedikleri liseye göre sonuçlar değerlendirildiğinde okul iklimi ölçeğinin "düzen ve disiplin”, “öğrencilerin kişilerarası ilişkileri” ve "ögrenci-öğretmen ilişkisi” boyutlarında tercihi İHL ve Fen lisesi olan öğrencilerin, tercihi Anadolu lisesi ve Meslek lisesi olanlara göre olumlu iklim algılarının daha yüksek olduğu görülmüştür. Bu değişkene göre öğrencilerin okula bağlllıkları değerlendirildiğinde "duygusal bağlllı" ve "bilişsel bağlllık" boyutlarında benzer bir sonuç olduğu belirlenmiştir. Bu durum, gelecek hedeflerine ve beklentilerine uygun bir okulda okuduklarını düşünen öğrencilerin, hedeflerine ulaşabilmek için daha sistemli çalıştıları, arkadaşlarıyla ve öğretmenleriyle ilişkilerinin daha iyi olduğu şeklinde açıklanabilir. Çünkü çeşitli araştırmalarda öğrencilerin kariyer hedeflerine ulaşmada okulun aracı rolünün varlığını önemsedikleri (Koç, 2020b, s. 639) ve gelecekte kendilerine yarar sağlayacak okula/derslere karşı daha fazla motive oldukları ifade edilmektedir (Koç, 2020c, s. 49). Araştırmada bu durumu ortaya koyan bir sonuç olarak; lise tercihi İHL ve Fen Lisesi olan öğrencilerin okula bağllılıları diğer öğrencilere göre daha yüksek düzeydedir. Meslek lisesine gitmek isteyen öğrencilerin ise gruplar arasında en düşük seviyede olumlu okul iklimi algisı ve okula bağlllık yaşadıkları görülmektedir. Buna göre gelecek hedeflerine ve beklentilerine uygun bir okulda okumanın öğrencilerin okul iklimi algılarını ve okula bağlılıklarını arttırdı̆̆ı söylenebilir. Literatüre bakıldığında İHO öğrencilerine yönelik iki ayrı çalışmada, İHL'ne devam etme isteğinde olan öğrencilerle devam etmek istemeyen ve başka bir liseyi öncelikli olarak düşünen öğrencilerin okul motivasyonlarının farklılaştığı, İHL'ne devam etmek isteyen öğrencilerin okul motivasyonlarının devam etmek istemeyen veya başka bir liseyi öncelikli olarak düşünenlere göre yüksek çıktığı belirtilmektedir (Aşlamacı, 2017; Çiftçi, 2019, s. 75).

Araştırma konusu olan okul iklimi ile okul bağlllığı ölçekleri arasında pozitif yönlü bir ilişkinin olduğu korelasyon analizinde tespit edilmiştir. Bu sonuca göre okul iklimi algisı yüksek olan öğrencilerin okula bağlılıklarının da yüksek olduğu; öğrencilerin yüksek düzeydeki okula bağlllı̆ıının da onların okula yönelik olumsuz tutumlarını engellediği ifade edilebilir. Literatüre bakıldığında öğrencilerin algiladığı olumlu okul ikliminin, okula bağl1lıkları üzerinde pozitif anlamda belirgin bir etkiye sahip olduğu (Dönmez, 2016, s. 66), olumlu iklim ile okula bağllık arasında orta düzeyde pozitif bir ilişkinin olduğu (Özgenel vd., 2018, s. 98), öğrencilerin okula bağlılık duygularının okula karşı olumsuz tutumlarını engellediği (Özdemir, 2015, s. 32) ifade edilmektedir.

Bu sonuçlara göre eğitimcilere ve araştırmacılara şu önerilerde bulunabilir:

Erkek öğrencilerin okul iklimi algılarını ve okula bağllıklarını yükseltmek için İHO’da erkeklere yönelik daha çok sosyal aktivite (spor, izcilik, gezi, piknik vb.) düzenlenebilir.

Yüksek olumlu iklim algısı ile İHO'ya başlayan öğrencilerin bu algısının aynı seviyede tutulabilmesi için sınıf rehberlik sistemi ve öğrenci koçluğu sistemi daha aktif hale getirilebilir. Üst sınıflara yönelik motivasyon programları düzenlenebilir.

Ortaokul döneminde yetişkin (okul yöneticisi/öğretmen) desteğinin önemi dikkate alınarak okulda öğrencilerle daha etkin bir ilişki ortamı kurulabilir. Yöneticinin/öğretmenin öğrenciye nasihat ettiği bir ilişki ortamından öğrencinin daha aktif olduğu, isteklerini ve görüşlerini daha çok ifade edebildiği bir ortam oluşturulabilir.

"Öğretmen-öğrenci ilişkisi” ve "bilişsel bağlllık" anlamında daha çok desteğe ihtiyacı olduğu ortaya çıkan yurt/kurs/pansiyonda kalan öğrencilere okul ortamında daha yoğun şekilde öğretmen ve yönetici 
desteği gösterilebilir. Bu öğrencilerin okul derslerine yönelik ilgilerini ve motivasyonlarını arttırmaya dönük tedbirler alınabilir.

Okul içindeki sosyal kulüp çalısmaları, etkinlikler ve aktiviteler resmi formattan ziyade, öğrencilerin "iyi ki bu okuldayım", "burası benim okulum” dedirtecek şekle dönüştürülebilir. Bu sayede öğrencilerin okula daha çok bağlanması, okulda daha mutlu olması ve okulun kendileri için daha anlamlı hale gelmesi sağlanabilir.

İHO’ya kendi isteğiyle gelen öğrencilerin okul iklimi algılarının ve okula bağlılıklarının daha yüksek olduğu dikkate alındığında her İHO yakınındaki ilkokullarda okuyan öğrencilere İHO'nun programı, ortamı, fiziki mekân ve imkânları, dersleri, sosyal faaliyetleri vb. hakkında bilgi verilebilir.

Lise tercihi İHL ve Fen Lisesi olan İHO öğrencilerinin okul ikilimi algılarının ve okula bağlılıklarının daha yüksek olduğu göz önünde bulundurularak sadece 8 .sınıf öğrencileri değil, henüz 6. ve 7.sınıfta okurken ögrenciler Fen liselerine ve proje tabanlı eğitim yapan IHL'lere götürülerek yüksek hedefler koymaları sağlanabilir.

\section{Etik Beyan}

"İmam Hatip Ortaokulu Ögrencilerinin Okul İklimi Algzlar ile Okula Bağhlıklar Arasındaki İliski”" başlıklı çalışmanın yazım sürecinde bilimsel kurallara, etik ve alıntı kurallarına uyulmuş; toplanan veriler üzerinde herhangi bir tahrifat yapılmamış ve bu çalışma herhangi başka bir akademik yayın ortamına değerlendirme için gönderilmemiştir. Bu araştırma, Yakın Doğu Üniversitesi Bilimsel Araştırmalar Etik Kurulu'nun 06.04.2020 tarih ve YDÜ/EB/2020/450 sayll izni ile uygulanmıştır.

\section{Kaynakça}

Akın, A., Sarıçam, H., Demirci, İ., Usta, F., Yalnız, A., Yıldız, B. ve Akın, Ü. (2013). Okul bağıllığı ölçeği’nin Türkçeye uyarlanması ve psikometrik özellikleri. İçinde İstanbul 2013 Dünya psikolojik danıs̆ma ve rehberlik kongresi bildiri özetleri kitabr (ss. 172-174). İstanbul: Boğaziçi Üniversitesi.

Aktaş, H. (2017). Genel ve İmam-hatip ortaokul ögrencilerinin okula bağlanma düzeyleri. Journal of Turkish Studies, 12/27, 335-358. doi: 10.7827/TurkishStudies.12316

Arslantaş, M. (2019). İmam-hatip ortaokullarnda örgün eğitimle birlikte bafıə̨hk projesinde ögrenci tutumları (Yüksek Lisans Tezi). Tokat Gaziosmanpaşa Üniversitesi Sosyal Bilimler Enstitüsü, Tokat.

Asslamac1, İ. (2017). Paydaşlarnna göre imam-hatip ortaokullarnda din eğitimi. İstanbul: Değerler Eğitimi Merkezi Yayınları.

Atik, G. ve Yerin-Güneri, O. (2016). Ortaokul öğrencileri için okul iklimi ölçeği: Türkçe formu'nun geçerlik ve güvenirlik çalışması. Illkögretim Online, 15/1, 91-103. doi: 10.17051/io.2016.42123

Brown, C. S. (2019). The importance, and the challenges, to ensuring an inclusive school climate. Educational Psychologist, 54/4, 322-330. doi:10.1080/00461520.2019.1655646

Büyüköztürk, Ş., Kilıç-Çakmak, E., Erkan-Akgün, Ö., Karadeniz, Ş. ve Demirel, F. (2019). Bilimsel araştrma yöntemleri (27. Basım). Ankara: Pegem Akademi Yayıncillk. doi:10.14527/9789944919289.

Büyüköztürk, Ş. (2020). Sosyal bilimler için veri analizi kitabı (27. Basım). Ankara: Pegem Akademi Yayınculık. doi:10.14527/978975680274

Coelho, V. A., Romão, A. M., Brás, P., Prioste, A. (2020). Trajectories of students' school climate dimensions throughout middle school transition: a longitudinal study. Child Indicators Research, 13/1, 175-192. doi: 10.1007/s12187-019-09674-y

Çelebi, M. ve Çopur, K. D. (2019). Öğrencilerin okula yönelik tutumları ile ailenin sosyoekonomik yapısı arasındaki iliş̧kinin belirlenmesi: Niğde ili örneği. OPUS Uluslararası Toplum Arastırmalarn Dergisi, 13/19, 786-814. https://doi.org/10.26466/opus.590974

Çiftçi, M. (2019). İmam hatip ortaokulu ögrencilerinin okul motivasyonlar (Eržrum ili örneği) (Yüksek Lisans Tezi). Atatürk Üniversitesi Sosyal Bilimleri Enstitüsü, Erzurum.

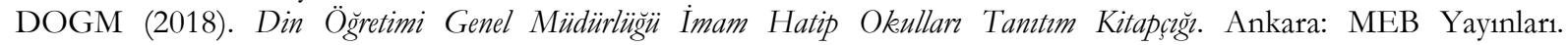
http://dogm.meb.gov.tr/pdf/ImamHatipTanitimKitapcigi.pdf

DOGM (2020). Din Ögretimi Genel Müdïrlïğ̈ Örgün Eğitimle Birlikte Hafįlı Projesi. Ankara: MEB Yayınları. http://hafiz.meb.gov.tr/pdf/okul\%20listemiz/hafiz_iho_listesi.pdf

Dönmez, Ş. (2016). Ortaokul ögrencilerinde okul iklimi, okula bağhlhk ve okul yaşam kalitesi algissmn incelenmesi (Yüksek Lisans Tezi). Muğla Sıtkı Koçman Üniversitesi Eğitim Bilimleri Enstitüsü, Muğla.

Dönmez, Ş. ve Taylı, A. (2018). Ortaokul öğrencilerinde okul iklimi, okula bağlllık ve okul yaşam kalitesi algısının incelenmesi. Adnan Menderes Üniversitesi Ĕ̈itim Fakültesi Eğitim Bilimleri Dergisi, 9/2, 1-17.

Erdem, İ. (2017). Imam batip lisesi bünyesindeki imam hatip ortaokullaryla müstakil imam hatip ortaokullarndaki örgüt kültürünün incelenmesi (Yüksek Lisans Tezi). İstanbul Sabahattin Zaim Üniversitesi Sosyal Bilimler Enstitüsü, İstanbul.

Erkan, D. (2019). Öğrenci gözïyle imam hatip ortaokullarnda motivasyon dïşïklï̆̈ünün sebepleri: Karabağlar örneği (Yüksek Lisans Tezi). Dokuz Eylül Üniversitesi Sosyal Bilimler Enstitüsü, İzmir. 
Fredricks, J. A., Blumenfeld, P. C. ve Paris, A. H. (2004). School engagement: potential of the concept, state of the evidence. Review of Educational Research, 74/1, 59-109. doi: 10.3102/00346543074001059

Gencer, N. (2019). İmam hatip lisesi öğrencilerinde okul aidiyet duygusu (Çorum örneği)”. Sakarya Üniversitesi İlahiyat Fakültesi Dergisi (SAUIFD), 149-172. doi: 10.17335/sakaifd.514384

Hoy, W. K. ve Hannum, J. W. (1997). Middle school climate: An empirical assessment of organizational health and student achievement. Educational Administration Quarterly, 33/3, 290-311. doi: 10.1177/0013161X97033003003

Hoy, W. K., Tarter C. J. ve Kottkamp, R. B. (1991). Open schools, healthy schools: measuring organizational climate. Newbury Park, Calif: Sage Publications.

Karababa, A., Oral, T. ve Dilmaç, B. (2018). Ortaokul öğrencilerinde okula bağlllı̆̆ın yordanmasında algilanan sosyal destek ve değerin rolü. Hacettepe Üniversitesi Eğitim Fakültesi Dergisi, 33/2, 269-279. doi: 10.16986/HUJE.2017028440

Kızıldağ, S., Demirtaş-Zorbaz, S. ve Zorbaz, O. (2017). School engagement of high school students”. TED Eğitim ve Bilim, 42/189, 107-119. doi: 10.15390/EB.2017.6740

Koç, A. (2020a). KKTC Hala Sultan İlahiyat Koleji mezunlarının kurumsal memnuniyet ve aidiyet düzeyleri. Pamukkale Üniversitesi Illabiyat Fakültesi Dergisi 7/2, 1457-1490. doi: 10.17859/pauifd.806815

Koç, A. (2020b). Hala Sultan İlahiyat Koleji mezunlarının okullarına yönelik örgütsel prestij algıları. Turkish Studies Religion, 15/4, 629-642. doi: 10.47091/TurkishStudies.44535

Koç, A. (2020c). A qualitative research on the problems and expectations of Imam Hatip Secondary School students (the case of Istanbul province). International Journal of Psychology and Educational Studies, 7/4, 43-51.

Libbey, H. P. (2004). Measuring student relationships to school: attachment, bonding, connectedness, and engagement. Journal of School Health, 74/7, 274-283. doi: 10.1111/j.1746-1561.2004.tb08284.x

Madjar, N. ve Cohen-Malayev, M. (2016). Perceived school climate across the transition from elementary to middle school. School Psychology Quarterly, 31/2, 270-288. doi: 10.1037/spq0000129

Malone, M., Cornell, D. G. ve Shukla K. (2020). Grade configuration is associated with school-level standardized test pass rates for sixth-, seventh-, and eighth-grade students. School Effectiveness and School Improvement, 31/2, $289-305$. doi: 10.1080/09243453.2019.1654526

Onuk, T. (2017). Ergenlerde kişilik özelliklerinin sınav kaygısı ve okula bağlanma stilleri üzerinde etkisi (Yayınlanmamış yüksek lisans tezi). Işık Üniversitesi Sosyal Bilimler Enstitüsü, İstanbul.

Özgenel, M., Yllmaz, F. ve Baydar, F. (2018). School climate as a predictor of secondary school students' school attachment. Eurasian Journal of Educational Research, 78, 87-116. doi: 10.14689/ejer.2018.78.5

Özdemir, S. Sezgin, F., Şirin, H., Karip, E. ve Erkan, S.(2010). İlköğretim okulu öğrencilerinin okul iklimine ilişkin algıllarını yordayan değişkenlerin incelenmesi. Hacettepe Üniversitesi Ë̆itim Fakültesi Dergisi, 38, 213-224.

Özdemir, Y. (2015). Ortaokul öğrencilerinde okul tükenmişliği: ödev, okula bağlllık ve akademik motivasyonun rolü. Adnan Menderes Üniversitesi Ë̆itim Fakültesi Eğitim Bilimleri Dergisi, 6/1, 27-35.

Şişman, M. ve Uysal, Ş. (2015). Okullarda kültür ve iklim. İçinde W. K. Hoy ve C. G. Miskel (Edt.), Eğitim Yönetimi: Teori, Arastırma ve Uygulama (7. Basım) (ss. 163-200). Ankara: Nobel Akademik Yayınc1lı.

Taş-Akarsu, N. (2018). Ortaokullarda moral iklim ile ögrencilerin okula bağhllklar arasındaki ilişkei (Yüksek Lisans Tezi). Firat Üniversitesi Eğitim Bilimleri Enstitüsü, Elazığ.

Tavşanlı, Ö. F., Oksal, A. ve Birgül, K. (2016). Ortaokul öğrencilerinin okul iklimine yönelik alg1larını yordayan değişkenlerin incelenmesi. Journal of Turkish Studies, 11/9, 821-838. doi: 10.7827/TurkishStudies.9616

Tong, L., Reynolds, K. J., Lee, E. ve Yangyang L. (2019). School relational climate, social 1dentity, and student wellbeing: new evidence from China on student depression and stress levels. School Mental Health, 11/3, 509-521. doi: 10.1007/s12310-018-9293-0

Topçu, N. (2019). Yatılı bölge ortaokullarnnda ögrenim gören ergenlerin ebeveyne, akrana ve okula bağlanma düzeylerinin incelenmesi (Yüksek Lisans Tezi). Bolu Abant İzzet Baysal Üniversitesi Eğitim Bilimler Enstitüsü, Bolu.

Ünald1, S. (2019). Imam hatip ortaokullari'nda okuyan ögrencilerin bu okullar tercih nedenleri ve beklentileri (Erz̨incan örneği) (Yüksek Lisans Tezi). Atatürk Üniversitesi Sosyal Bilimleri Enstitüsü, Erzurum.

Yetimova, P. (2018). Ortaokula devam eden ögrencilerin hafı̨̆lk eğitiminde yaşanan sorunlar ve çözü̈m önerilerine yönelik bir araştırma (Yüksek Lisans Tezi). İstanbul Üniversitesi Sosyal Bilimler Enstitüsü, İstanbul.

\section{EXTENDED ABSTRACT}

School climate is defined as the whole dynamics that shape the behavior of people in the school, make the school distinct from other schools, and include many variables (Özgenel, Y1lmaz, \& Baydar, 2018, p. 98). A student's feeling of belonging to the school, loving school, teacher support and interest, having good friends at school, compliance with the current and future academic method, and presence of an effective discipline method are all determinants of school engagement (Karababa, Oral, \& Dilmaç, 2018, p. 269). It is possible to say that Imam Hatip Secondary Schools (IHSS) is a unique experience for our country, whose roots go back to the last periods of the Ottoman State, combining social sciences, science with Islamic sciences in the same curriculum. A school climate and school culture is unique to these schools because of the educational content and shape given in these schools (Çiftçi, 2019). The 
majority of the studies on the evaluation of school climate and school engagement are based on the opinions of school administrators and teachers. In this respect, this study is important to evaluate students' perceptions about school climate and school engagement. The purpose of this study is to determine the relationship between the school climate perceived by the students studying at IHSS and their engagement to school. Firstly, this research examined whether students' perceptions of school climate and school engagement differ according to various variables. Secondly, the level of relationship between perceptions of school climate and their engagement to school was determined.

The research was carried out in 2020 with the participation of 481 students studying at 11 IHSSs in Istanbul. Two scales were used in this quantitative study: 1. "School Climate Scale", which was developed in 2005 by Emmons and friends, and adapted to Turkish in 2016 by Atik and Yerin-Güneri (2005, p. 101). 2. "School Engagement Scale", which was developed in 2005 by Fredericks and friends, and adapted to Turkish in 2013 by Akın and friends (Akin et al., 2013, p. 172). In this research the following results were reached:

It was determined that female students evaluated two dimensions of the school climate scale and all dimensions of the school engagement scale with a significantly higher score compared to male students. It can be said that female students are more motivated to school and education and use communication more effectively in solving their problems within the school (Özgenel et al., 2018, p. 94; Dönmez, 2016, p. $55)$.

It was defined that there is a significant difference between the grade levels except "parent participation" dimension in all dimensions of both scales. It was found that perceptions of school climate and school engagement of 5th grade students were higher than other classes, and both scale scores decreased significantly towards upper grades in general. The reason for this may be the fact that younger students are more willing to learn in secondary school period, the students coming to IHSS experience academic anxiety as their grade level rises and the psychological processes they experience during adolescence (Malone, Cornell, \& Shukla, 2020, p. 301; Aktaş, 2017, p. 344).

It was determined that the positive climate perceptions and engagement to school of the students staying at their homes are higher than that the students staying at dormitory. Accordingly, it can be said that middle school children are very attached to their parents, students who are away from their families have more difficulty in motivating lessons and need more adult (teacher) support (Topçu, 2019, p. 70).

It was identified that the positive climate perceptions and engagement to school of the students studying at IHSS voluntarily are higher than the students who come with the request of their parents or with the advice of friends/teachers. Accordingly, it can be said that students who come to IHSS voluntarily have more motivation towards school and education (Erkan, 2019, p. 84; Çiftçi, 2019, p. 68; Koç, 2020a, p. 1484).

Students who have high school preference Imam Hatip High School (IHHS) and Science High School have higher perceptions of school climate and school engagement than other students do. Accordingly, it can be said that students who think that they are studying in a secondary school that is in line with their future goals, work more systematically to reach their goals, and have better relations with their friends and teachers (Aşlamac1, 2017; Çiftçi, 2019, p. 75; Koç, 2020b, p. 639; Koç, 2020c, p. 49).

It was determined in the correlation analysis that there is a strong positive relationship between the school climate and the school engagement scales. According to this result, students with a high perception of school climate have school high engagement. It can be stated that students' high level of engagement to school prevents their negative attitudes towards school (Dönmez, 2016, p. 66; Özgenel et al., 2018, p. 98),

Qualitative and mixed research can be conducted in order to reveal the reasons that increase and decrease students' perceptions of school climate and their engagement to school. 